\title{
Developing an Extended Model of Theory of Planned Behavior to Explore Green Purchase Behavior of Pakistani Consumers
}

\author{
Nazish Muzaffar \\ Department of Business Administration, Fatima Jinnah Women University, Rawalpindi, Pakistan
}

\begin{abstract}
The study proposes and tests an extended model of theory of planned behavior. Cross sectional data was collected from 7 major cities of Pakistan, through a self-administered survey of 679 respondents. The appropriateness of theory and conceptual framework were tested using structural equation modeling (SEM). The extended model accounted for the substantial amount of variance in environmentally conscious purchase behavior of Pakistani consumers $\left(R^{2}=0.934\right)$. Specific findings revealed that 1$)$ all predictors except environmental knowledge were significantly co related with ECPB 2) subjective norms and perceived product availability emerged as strongest predictors of environmentally conscious purchase behavior. Model yielded an $\mathrm{R}^{2}$ of 2.019 a CFI 0.985, GFI0.945, AGFI 0.947 and a RMSEA of 0.03. The value of study is; it considers the proper role of Subjective norm, which is often neglected or its exploratory powers are often being under estimated in past studies conducted in Asian region. Moreover study generates many important implications for marketers and policy makers.
\end{abstract}

Key Words: Environmentally conscious purchase behavior, theory of planned behavior, Pakistani Consumers

\section{Background of Study}

Green purchase or environmentally preferable products purchase means purchase of those products or services that have a lesser or reduced effect on human health and the environment when compared with competing products or services that serve the same purpose," (U.S Environmental Protection Agency, 1993).

Green marketing concept is not something new; it dates back to World War II or even before (Ajay, 2009). However from the past few decades this has gone through pronounced transformations. The issue has been much escalated from a decade or so,it has been driven by the number of factors including enhanced coverage, advanced environmental knowledge, increased green product awareness, rise of pressure groups and governmental legislations not to mention (Kalafatiset al., 1999; McIntosh, 1991; Butler, 1990; Tapon \& Leighton, 1991; Charter, 1992; Wagner, 1997). Consequently consumers became more conscious of about the outcomes of their act on environment.

Research on the subject matter continued and various interest groups realized that diagnosing environmental problems merely would not render the purpose rather they need to extend their efforts way beyond. This thing triggered the debate on sustainable environment (Lubchenco et al., 1991; Rosen\& Dinser, 2001). Business units in western countries have realized the trend and perceived this as potential opportunity (Steg \& Vlek, 2009; Roberts, 1996). History has witnessed that voice of these environmental concerns was heard loud and clear in urbanized and developed nations. (Gurao \&Ranchhoh, 2005; Kalafatis et al., 1999; Muderrisoglu\& Altanlar, 2011). In under developed countries like Pakistan it is considered as western luxury. While rest of the world was busy in creating environment related awareness and finding ways to rescue environment from human interventions there was a part of world busy in bugging off political unrest and trying to get out of the vicious circle of poverty.

However, past couple of years has witnessed a progress in this regard. There are few companies who have stepped into this green arena and are taking extra strides to protect environment by formulating and marketing environmental friendly products. Quite recently Pakistan State Oil (PSO) has rolled out an environment friendly Diesel variant termed as "Bio Diesel". Sources have claimed that PSO is using Jatr-

\author{
Corresponding author: Nazish Muzaffar \\ Department of Business Administration, Fatima Jinnah \\ Women University, Rawalpindi, Pakistan, Email: \\ neesh25@hotmail.com
}
CC This article is distributed under the terms of the Crea- tive Commons Attribution License, which permits unre- stricted use and redistribution provided that the original author and source are credited.


opha Curcus; an environmental friendly shrub to minimize the impact of diesel on environment (PSO official report Sep 2010). But this initiative from PSO has just barely scratched the surface. Moreover people are having a very little knowledge and awareness about this green initiative. In order to make these kinds of initiatives really work green industry needs to market and support its products through marketing communication (Hartmann, Ibanez \& Sainz, 2005). Race has just started yet; there is a lot more room for improvement.

\section{Explanatory theories and their applicability}

Research used theory of Reasoned Action (TRA) and Theory of Planned Behavior (TPB) and sought its applicability on the green purchase behavior. Theory is a widely accepted frame work, tapping behavioral intentions. It has previously been applied to a wide array of disciplines, be it determinants effecting choice of green hotel (Han, Hasu \& Sheu, 2010; Han \& Kim, 2010; Lam \& Hsu, 2004; Quintal, Lee \& Souter, 2010), TPB and social networking (Chaubey \&Subramanian, 2010; Mathieson, 1991; Pelling \& White, 2009), TPB on health behavior and health education (Glanz, Rimer, \&Viswanath, 2008) or else (Stead \& Eadie, 2005; Elliot et al., 2005; Godin \& Kok, 1995; Conner \& Armitage, 1998; Chen and Tung 2014; Mohammad et al., 2014).

Moreover applicability of this theory on determining green purchase behavior, intentions and patterns also warrants the further investigation and research (Kalafatis, Pollard, \& Eas, 1999; Vermeir \&Verbeke, 2006; Tarkiainen \&Sundqvist, 2005 \& Bipu;, 2102).

\section{Research Objectives}

The research is erected around the following objectives

a) To seek the applicability of theory of planned behavior upon green purchase behavior.

b) To study and analyze the understating and viewpoints of Pakistani consumers about environmental problems and how these problems will affect their behavior to buy green products i.e. determinants of green purchase behavior.

c) To identify the antecedents of Environmentally Conscious Purchase Behavior (ECPB).

d) To analyze the three subcomponents within the TPB concept of PBC in an omnibus model.

\section{Literature Review}

\section{Environmental Attitude and behavioral intention}

Attitude has been defined as the mental state of readiness. Attitude in its simplest sense is the way how a person reacts or behaves towards a particular object or else (Allport, 1935). On the other hand a favorable attitude towards a product which is environmentally sustainable is environmental attitude (Chan, 2001; Verbeke \& Viaene, 1999; Tanner \& Kast, 2003; Vermeir \& Verbeke, 2004).

Attitude Impacts intentions to perform or not to perform a particular behavior, the more favorable the attitude, stronger will be intention to perform that very behavior. (Smith \& Paladino, 2010; Hill \&Lynchehaun, 2002).

Various researches has established that attitude acts as an important (and major contributing perhaps) antecedent towards behavioral intention (Ajzen, 1991; Mannell \&Kleiber, 1997; Kaiser, Wolfing \& Fuhrer, 1991; Kaiser, Wlofing and Fuhrer, 1999; Taylor \&Todd, 1995; Kelly et al., 2006; Manaktola \& Jauhari, 2007;Rhodes, Macdonald \& McKay, 2006; Everson, Daley \& Ussher, 2007). Leonidou, Leonidou and Kvasova, 2010 in their study established that consumers showing ecological attitude are more likely to engage in purchase of recyclable and biodegradable products (Laroche et al., 2001; Shabecoff, 1993; Festinger, 1957; Kilbourne \&Pickett, 2008; Mostafa, 2007; Roberts \&Bacon, 1997; Squires et al., 2001; Kilbourne \& Pickett, 2008; Steg, Dreijerink, \& Abrahamse, 2005; Downs \& Hausenblas, 2003; Fen \& Sabaruddin, 2008; Roddy et al., 1996; Tarkiainen, Sundqvist \& Sanna,2005; Brucks, 1985; Park, Mothersbaugh \&Feick, 1994). On the basis of above literature it can be hypothesized as:

HI: Environmental Attitude positively impacts the behavioral intentions towards purchasing green products.

\section{Environmental knowledge and Behavioral inten- tion}

It is the level of awareness amongst the individuals, active linkages between the environment and sense of awareness to keep the environment intact of human interaction and to preserve it for future generations (Kumar, 2012). Chan (2001) explained it as one's ability to understand and evaluate the impact of ecosystem on society together with the amount of knowledge that he/she is having regarding environment.

There are plenty of researches which have tested environment knowledge and behavior relationship, it is widely held that environmental knowledge will trigger environmental concern, which in turn stimulates green purchase behavior and green consumption (Tan, 2011; Oskamp, Harrington, Edwards, Sherwood, Okuda and Swanson, 1991;Vining \& Ebreo, 
1990; Hines et al., 1986-1987; Schmidt, 2007; Mittal, 1989; Laroche et al.,2000). In another study conducted by Kaiser (1999) environmental knowledge together with environmental values explained $40 \%$ variance in ecological behavior.

Lee (2010) in his study declared environmental knowledge to be the third most (peer influence and local environmental involvement being the first and second) powerful predictor of environmental behavior of Hong Kong adolescents.) established knowledge as a key part in the process of making decision to buy green products.

H2: Environmental knowledge positively impacts the behavioral intention towards purchasing green products.

\section{Subjective norms and behavioral intention}

Ajzen (1991) defines subjective norm as a perceived societal force to carry a particular behavior. Tarkiainen and Sundqvist (2005) established that subjective norm affect behavioral intentions indirectly through attitude formation, whereas Robinson and Smith (2002) established subjective norms affect intentions independently. Many other studies conducted on organic buying intention found subjective norm and purchase intention relationship significant (Tamashiro,Silveira, Merlo \& Ghisi, 2013; Nejati, Salamzadeh \&Salamzadeh, 2011; Werner \&Alvensleben, 2011; Dean et al., 2008;Hines et al., 1986/87; Kim and Choi, 2005; Siddique et al., 2010 \& Shaw, 2008).

Vermier and Verbeke (2006) in their study conducted on purchase of dairy products identified that willingness to comply with others might define powerful intention to buy sustainable dairy goods regardless of having low attitude (Gotschi et al., 2007).

Subjective norm is of particular importance in collectivistic societies where individuals are in a better position to exert societal pressure on others $(\mathrm{Ku}-$ mar, 2012; Shabnum, 2013; Arvola, Vassallo, and Dean et al., 2008; Sinha et al., 2001; McCarty \& Shrum, 1994; Triandis et al., 1988; Kalafatis et al., 2009). Hence on the basis of this it can be hypothesized that

H3: Subjective norms positively impact on behavioral intentions towards purchasing green products.

\section{Self-Concept and behavioral intention}

Self-concept (also called self-image) is what people want to portray of themselves and how they want others to see them (Faurst\& Smardon, 2001).It can actually be tied with personal norm, experienced as a feeling of moral obligation (Schwartz, 1973, 1977); it refers to "what I am morally obliged to do" and motivates the behavior to act in a particular way (Minton \& Rose, 1997). Rehman and Dost (2013) established in their study (held in Pakistan) that behavioral intentions are positively impacted by the self-concept. People buy green products to portray a positive image of them (Christensen, Rothberger, Wood, \& Matz, 2004; Schiffman \&Kanuk, 1997; Lee, 2008; Dittmer, 2009; Terry, Hogg, \& White, 1999; Cook et al., 2002; Grewal, Mehta, \& Kardes, 2000;Sparks \& Shepherd, 1992; Shaw and Shiu, 2002a, b, 2003; Armitage \& Conner, 2001; Terry et al., 1999 \& Sparks \& Guthrie, 1998; Biddle, Bank, \& Slavings, 1987)

Charng et al. (1998) established that repeated behaviors influence a person self-concept which then becomes important to that person. (Granberg and Holmberg, 1990; Fliegenschnee and Schelakovsky, 1998).Armed with the literature findings discussed, it can better be hypothesized as

H3: Self image positively impacts behavioral intentions towards purchasing green products.

\section{Perceived behavioral control and behavioral in- tention towards the green purchase behavior}

Perceived behavioral control is the individual perception of possible difficulties that they can encountered with while performing a specific behavior (Ajzen, 1991). The external and irrational factors such as money (in terms of price), access (in terms of availability) and efficacy (in terms of individual confidence that he/she can perform that particular behavior) may not be under the control of individuals. Therefore, the more individuals are able to have control over these the more likely they will try to engage in the performance of that behavior (Chen \&Tung, 2014).

In context of present theory three determinants of perceived behavioral control are incorporated i.e. price of the green products, their availability and consumer efficacy to use them.

A number of studies have operationalized affordability (in terms of price) as a subset of behavioral control in influencing behavioral intention (Thompson \& Thompson, 1996; Notani, 1997; ACNielsen, 2005; Voon, et al., 2011; Tregear et al., 1994; Magnusson et al., 2001; Vermeir \& Verbeke, 2006). Many researchers have indicated that green products are mostly purchased by high income households and individuals (Dettmann \&Dimitri, 2009; Zhang et al., 2008). On the basis of above discussion it can be hypothesized that:

H5: Price negatively impacts the behavioral intention towards purchasing green products.

Availability is the convenience with which individuals can access green products. Several researches 
have established that the easier it is for individuals to access a green product more likely are they to engage in their purchase (Voon et al., 2011; Kumar, 2012; Harris et al., 2000). Many studies pointed out low availability as a significant reason for not engaging into green purchase behavior (Vermier \& Verbeke, 2008;Sparks \& Shepherd 1992;Fotopoulos \& Krystallis, 2002). Delafrooz et al., (2014) established advertisement to be the most powerful predictor of consumer green purchase behavior. He argues greater will be product visibility more likely are the individuals to exhibit the desired purchase behavior ( Juwaheer, Pudaruth \&Emmanuelle, 2012). On the basis of this following hypothesis can be chalked out.

H5a: Control on availability of green products positively impacts behavioral intention towards purchasing green products.

\section{Behavioral intention and Environmentally Con- scious purchase behavior (ECPB)}

Environmental consciousness is the propensity to the engage in pro environmental purchase behavior (Zelezny \& Schultz, 2000). Kaiser, Wolfing and Fuhrer (1999) established in their research that behavioral intentions caused 75 percent of variance in environmentally conscious purchase behavior. Mostafa (2007) indicated a relationship, in his research conducted on Egyptian consumers (Richard, Lucie \& Renee et al., 2006) .On the basis of above literature following hypothesis can be formulated

H6: Behavioral intentions positively impact the Environmentally Conscious Purchase Behavior.

On the basis of above literature following model can be proposed

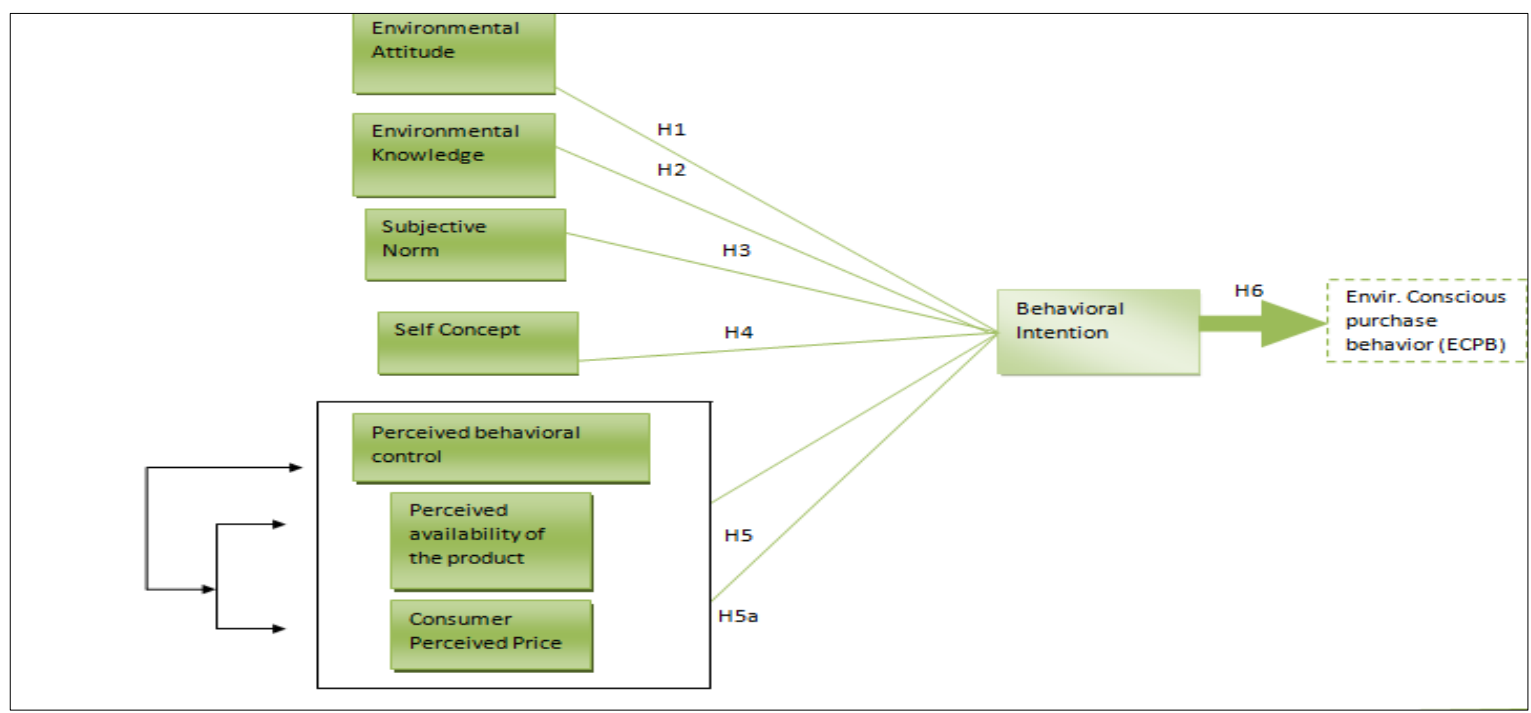

Figure 1, Theoretical frame work, showing exogenous variables on left and endogenous on far right.

Model intends to check the impact of all of these variables on behavioral intention and then the impact of behavioral intention on environmentally conscious purchase behavior.

\section{Methodology}

\section{Samples and procedures}

The consumer is the unit of analysis in this research. Most of the researches on environment have mostly taken students as sample size (Mostafa, 2007; Kumar, 2012; Rehman \& Dost, 2013; Shabnam, 2013), unlike these researches present study has taken those individuals who have real income and are consumers in true sense, so students are excluded from the sam- ple. Questionnaire survey was used to collect data. In order to make research truly Pakistan focused, data was collected from the 7 major cities (Islamabad, Rawalpindi, Karachi, Lahore, KPK, Quetta and Gujranwala) of Pakistan. The questionnaire was selfadministered to a convenience sample consisting of 700 respondents. Out of these, 21 respondents were not considered on the account of incomplete responses. Finally 679respondents qualified for final sample size. This much sample size permeates the rule of 10 , quite generously. Rule of 10 suggests that there should be at least 10 cases for each item in the instrument being used (Garson, 2008; Everitt, 1975; Kunce, Cook, \& Miller, 1975, Marascuilor \& Levin, 1983). 


\section{Instrumentation}

The survey questionnaire was divided into the two sections; first section catered the variables used in study whereas the second section captured the demographic profile of respondents. The established validated scales were used for measuring all latent variables. Each variable was measured on a 5 point Likert scale where 1 denotes "strongly disagree" and 5 denotes "strongly agree". No item was reverse coded.

\section{Data Collection Plan}

Responses were collected deploying Non probability convenience sampling; where sample is drawn to the population that is close to hand, easily reachable and readily accessible (Saunders et al., 2009). Prior to presenting the questionnaire to actual respondents, the items of the questionnaire were discussed with 10

Table 1. Demographics of Respondents consumers. Target respondents from each city were identified using following criteria: a) they are at least 25 years of age 2 )are engaged in full time or part time employment c)are able to respond comprehensively to an English- language survey questionnaire.

\section{Data Analysis procedure}

Data analysis was done using SEM, Amos. SEM is preferred over OLS (ordinary least square) for multiple reasons i.e. it allows both confirmatory and exploratory modeling. It can be used for both theory testing and theory development (Alavifar, Karimimalayer \& Anuar, 2012; Muthen \& Satorra, 1995).

\section{Data Analysis}

Demographics profile and sample descriptive statistics

\begin{tabular}{|c|c|c|}
\hline & $\mathrm{N}$ & Percentage \\
\hline Male & 384 & $56.6 \%$ \\
\hline$\overline{\text { Female }}$ & 295 & $43.4 \%$ \\
\hline \multicolumn{3}{|l|}{ Age } \\
\hline $25-34$ & 361 & $53.2 \%$ \\
\hline $35-44$ & 180 & $26.5 \%$ \\
\hline $45-54$ & 88 & $13.0 \%$ \\
\hline 55 and above & 50 & $7.4 \%$ \\
\hline $25-34$ & 361 & $53.2 \%$ \\
\hline \multicolumn{3}{|l|}{ Education } \\
\hline High School & 20 & $2.9 \%$ \\
\hline 2 years collage degree & 70 & $10.3 \%$ \\
\hline 4 years collage degree & 212 & $31.2 \%$ \\
\hline Master's degree & 206 & $30.3 \%$ \\
\hline Doctoral degree & 85 & $12.5 \%$ \\
\hline Professional degree & 86 & $12.7 \%$ \\
\hline \multicolumn{3}{|l|}{ Occupation } \\
\hline Unemployed and searching & 30 & $4.4 \%$ \\
\hline Entry level & 136 & $20.0 \%$ \\
\hline Managers/Professionals & 217 & $32.0 \%$ \\
\hline Self employed & 151 & $22.2 \%$ \\
\hline Others & 145 & $21.4 \%$ \\
\hline \multicolumn{3}{|l|}{ Income } \\
\hline$<10,000$ & 21 & $3.1 \%$ \\
\hline $10,000-19,000$ & 67 & $9.9 \%$ \\
\hline $20,000-29,000$ & 82 & $12.1 \%$ \\
\hline $30,000-39,000$ & 88 & $13.0 \%$ \\
\hline $40,000-49,000$ & 138 & $20.3 \%$ \\
\hline $50,000-59,000$ & 77 & $11.3 \%$ \\
\hline $60,000-69,000$ & 65 & $9.6 \%$ \\
\hline $70,000-79,000$ & 63 & $9.3 \%$ \\
\hline $80,000-89,000$ & 40 & $5.9 \%$ \\
\hline $90,000-99,000$ & 13 & $1.9 \%$ \\
\hline 100,000 and above & 25 & $3.7 \%$ \\
\hline \multicolumn{3}{|l|}{ City } \\
\hline Karachi & 121 & $19.2 \%$ \\
\hline Peshawar & 75 & $11.9 \%$ \\
\hline Islamabad & 77 & $12.2 \%$ \\
\hline Rawalpindi & 98 & $15.5 \%$ \\
\hline Quetta & 107 & $17.0 \%$ \\
\hline Lahore & 75 & $11.9 \%$ \\
\hline Gujranwala & 78 & $12.4 \%$ \\
\hline Total & 631 & $100.0 \%$ \\
\hline
\end{tabular}


Since the environmental debate is on its nascent stage and it is somehow considered to be a luxury of educated class so in order to ensure this almost entire responses were drawn from the educated and wellheeled people. In order to bid the testimony of previ- ous statement highest amount of responses (63\%) were pooled from those having four years collage degree and master's degree, serving on managerial and executive posts. Reliability values of all the latent variables extracted ranges from 0.7 to 0.9 .

Table 2. Cronbach's Alpha Coefficients

\begin{tabular}{llllll}
\hline Latent Variables & No of items & $\begin{array}{l}\text { Cronbach's Alpha } \\
\text { Coefficient }\end{array}$ & $\begin{array}{l}\text { Items Re- } \\
\text { moved }\end{array}$ & $\begin{array}{l}\text { Revised Cronbach's } \\
\text { Alpha Coefficient }\end{array}$ & $\begin{array}{l}\text { Revised Guttman } \\
\text { Lambda 6 }\end{array}$ \\
\hline EA & 3 & 0.983 & 0 & 0.983 & 0.976 \\
EK & 3 & 0.861 & 0 & 0.861 & 0.809 \\
SN & 4 & 0.943 & 0 & 0.943 & 0.927 \\
SC & 4 & 0.760 & 2 & 0.922 & 0.856 \\
PPA & 3 & 0.901 & 0 & 0.901 & 0.861 \\
PCP & 6 & 0.902 & 2 & 0.841 & 0.849 \\
BI & 4 & 0.695 & 2 & 0.853 & 0.745 \\
ECPB & 6 & 0.895 & 2 & 0.908 & 0.883 \\
\hline
\end{tabular}

Table 3. Composite Reliability

\begin{tabular}{lllll}
\hline $\begin{array}{l}\text { Latent Variab } \\
\text { Les }\end{array}$ & No of Indicators & Sum of St loading square & $\begin{array}{l}\text { Sum of indicator meas- } \\
\text { urement error }\end{array}$ & $\begin{array}{l}\text { Composite Reliability } \\
\text { (CR) }\end{array}$ \\
\hline EA & 3 & 8.56 & 0.07 & 0.99 \\
EK & 3 & 6.08 & 0.53 & 0.91 \\
SN & 4 & 12.88 & 0.41 & 0.97 \\
SC & 2 & 3.43 & 0.15 & 0.96 \\
PPA & 3 & 6.79 & 0.39 & 0.94 \\
PCP & 3 & 6.62 & 0.43 & 0.94 \\
BI & 2 & 2.98 & 0.27 & 0.92 \\
ECPB & 4 & 11.42 & 0.62 & 0.95 \\
\hline
\end{tabular}

These figures represent the overall reliability of a multi-dimensional construct. Reliability statistics ranges from 0.91 to 0.99 , which is particularly significant. Data is normal and negatively skewed with relatively flat peak.

Average Variance Extracted (AVE). According to Fornell and Lacker (1981) Average Variance Extracted is the estimate which measures the amount of variance captured by a construct in relation to the variance due to random measurement error. AVE varies from 0 to 1 , and it represents the ratio of the total variance that is due to the latent variable. Following formula is used to calculate the AVE

$\mathrm{AVE}=$ (sum of squared standardized loading) / (sum of squared standardized loading + sum of indicator measurement error). Whereas sum of indicator measurement error $=1$ minus the square of each loading)

Table 4. Average variance extracted

\begin{tabular}{lllll}
\hline $\begin{array}{l}\text { Latent Varia- } \\
\text { bles }\end{array}$ & No of Indicators & Sum of squared St loading & $\begin{array}{l}\text { Sum of indicator meas- } \\
\text { urement error }\end{array}$ & $\begin{array}{l}\text { Average Variance } \\
\text { Extracted (AVE) }\end{array}$ \\
\hline EA & 3 & 2.86 & 0.07 & 0.98 \\
EK & 3 & 2.03 & 0.53 & 0.79 \\
SN & 4 & 3.22 & 0.41 & 0.89 \\
SC & 2 & 1.71 & 0.15 & 0.92 \\
PPA & 3 & 2.39 & 0.39 & 0.86 \\
PCP & 3 & 2.21 & 0.43 & 0.84 \\
BI & 2 & 1.49 & 0.27 & 0.85 \\
ECPB & 4 & 2.86 & 0.62 & 0.82 \\
\hline
\end{tabular}


The significant value of AVE is 0.5 and above (Dillon \&Goldstein, 1984; Bagozzi, 1994) As per above table AVE values varies from 0.7to 0.9. As per above statistics latent variables are bringing significant variation in the face of random measurement error.

Convergent Validity. Convergent validity is the subtype of construct validity and it can be defined as; measures of construct that theoretically should be related to each other, are in fact observed to be related to each other i.e. you should be able to show correspondence or convergence between the similar constructs (Trochim, 2008).

Convergent validity requires squared multiple correlations (SMC) to be equal to or greater than 0.5 with pattern coefficients equal to or greater than 0.7 .

Table 5. Convergent Validity

\begin{tabular}{lcc}
\hline Observed Variable & Factor Loadings & $\begin{array}{c}\text { Squared Multiple Correla- } \\
\text { tion (SMC) }\end{array}$ \\
\hline EA1 & & 0.950 \\
EA2 & 0.975 & 0.977 \\
EA3 & 0.989 & 0.927 \\
EK1 & 0.963 & 0.628 \\
EK2 & 0.792 & 0.796 \\
EK3 & 0.892 & 0.611 \\
SN1 & 0.875 & 0.813 \\
SN2 & 0.902 & 0.817 \\
SN3 & 0.904 & 0.829 \\
SN4 & & 0.765 \\
& & \\
SC2 & 0.910 & 0.839 \\
SC3 & 0.875 & 0.874 \\
PPA1 & 0.916 & 0.709 \\
PPA2 & 0.935 & 0.764 \\
PPA3 & 0.842 & 0.791 \\
PCP3 & 0.874 & 0.731 \\
PCP4 & 0.889 & 0.759 \\
PCP5 & 0.855 & 0.717 \\
B13 & 0.871 & 0.789 \\
B14 & 0.847 & 0.705 \\
ECPB3 & 0.888 & 0.660 \\
ECPB4 & 0.839 & 0.751 \\
ECPB5 & 0.813 & 0.770 \\
ECPB6 & 0.867 & 0.677 \\
\hline
\end{tabular}

All of the three conditions of convergent validity are satisfactorily met i.e. regression weights/ factor loadings are equal to and greater than 0.5 whereas SMC's are equal to and greater than 0.7 and AVE values are equal to and greater than 0.5 . All of the aforementioned conditions confirm convergent validity of construct.

Discriminant validity. Discriminant validity is another type of construct validity, for construct to be valid both of the conditions should be checked. Discriminant validity analysis refers to testing statistically whether two constructs differ from each other or not.
It holds that indicators for different constructs should not be so highly correlated as to lead one to conclude that they measure the same thing. This would happen if there is cross loading or definitional overlap between constructs.

Fornell and Larker's (1981) suggested average variance extracted (AVE) method to conclude discriminant validity. According to them AVE for each variable should be greater than the squared correlation of each variable (Netemeyer, Johnston and Burton, 1990) 
Table 6. Discriminant Validity

\begin{tabular}{|c|c|c|c|c|c|c|c|c|c|c|c|}
\hline Variable & $\begin{array}{l}\text { No of } \\
\text { Items }\end{array}$ & Mean & SD & $\begin{array}{l}\text { EA } \\
1\end{array}$ & $\begin{array}{l}\text { EK } \\
2\end{array}$ & $\begin{array}{l}\mathrm{SN} \\
3\end{array}$ & $\begin{array}{l}\mathrm{SC} \\
4\end{array}$ & $\begin{array}{l}\text { PPA } \\
5\end{array}$ & $\begin{array}{l}\text { PCP } \\
6\end{array}$ & $\begin{array}{l}\text { BI } \\
8\end{array}$ & $\begin{array}{l}\text { ECPB } \\
9\end{array}$ \\
\hline$\overline{\mathrm{EA}}$ & 3 & 3.67 & 0.81 & 0.98 & & & & & & & \\
\hline EK & 3 & 3.70 & 0.82 & $\begin{array}{l}0.65 \\
(0.42)\end{array}$ & 0.79 & & & & & & \\
\hline SN & 4 & 3.40 & 0.92 & $\begin{array}{l}0.16 \\
(0.02)\end{array}$ & $\begin{array}{l}0.78 \\
(0.60)\end{array}$ & 0.89 & & & & & \\
\hline $\mathrm{SC}$ & 2 & 3.32 & 0.92 & $\begin{array}{l}0.14 \\
(0.02)\end{array}$ & $\begin{array}{l}0.11 \\
(0.01)\end{array}$ & $\begin{array}{l}0.73 \\
(0.53)\end{array}$ & 0.92 & & & & \\
\hline PPA & 3 & 3.44 & 0.89 & $\begin{array}{l}0.14 \\
(0.02)\end{array}$ & $\begin{array}{l}0.10 \\
(0.01)\end{array}$ & $\begin{array}{l}0.75 \\
(0.56)\end{array}$ & $\begin{array}{l}0.80 \\
(0.64)\end{array}$ & 0.86 & & & \\
\hline PCP & 3 & 3.34 & 0.90 & $\begin{array}{l}0.13 \\
(0.20)\end{array}$ & $\begin{array}{l}0.49 \\
(0.24)\end{array}$ & $\begin{array}{l}0.76 \\
(0.57)\end{array}$ & $\begin{array}{l}0.62 \\
(0.38)\end{array}$ & $\begin{array}{l}0.80 \\
(0.64)\end{array}$ & 0.84 & & \\
\hline BI & 4 & 3.55 & 0.79 & $\begin{array}{l}0.18 \\
(0.03)\end{array}$ & $\begin{array}{l}0.38 \\
(0.14)\end{array}$ & $\begin{array}{l}0.72 \\
(0.52)\end{array}$ & $\begin{array}{l}0.52 \\
(0.27)\end{array}$ & $\begin{array}{l}0.80 \\
(0.64)\end{array}$ & $\begin{array}{l}0.77 \\
(0.59)\end{array}$ & 0.85 & \\
\hline ЕCРB & 4 & 3.45 & 0.87 & $\begin{array}{l}0.20 \\
(0.04)\end{array}$ & $\begin{array}{l}0.78 \\
(0.60)\end{array}$ & $\begin{array}{l}0.68 \\
(0.46)\end{array}$ & $\begin{array}{l}0.44 \\
(0.19)\end{array}$ & $\begin{array}{l}0.72 \\
(0.51)\end{array}$ & $\begin{array}{l}0.76 \\
(0.57)\end{array}$ & $\begin{array}{l}0.78 \\
.60\end{array}$ & 0.82 \\
\hline
\end{tabular}

*Shared correlations are in parenthesis

**AVE is on diagonal

By comparing variance of constructs with parameter of constructs it can easily be find out that correlation squares are less than that of AVE, hence confirms the discriminant validity of construct.

\section{Confirmatory Factor Analysis and Structural Equa- tion Modeling (SEM)}

In structural equation modeling, confirmatory factor analysis (CFA) is used to calculate fit indices. These indices then establish whether, overall model is ac- ceptable or not. If model is acceptable, researchers than establish whether specific paths are significant or not.

The Structural Equation Modeling (SEM) was employed to test the test the five hypotheses, proposed earlier. This analytical technique allows the evaluation of the overall fit of the proposed model and the estimation of all the corresponding path coefficients simultaneously (Hair et al., 1995; Chan \& Lau, 2014).

Table 7. Structural path coefficients

\begin{tabular}{|c|c|c|c|c|}
\hline Causal Path & $\begin{array}{l}\text { Standardized Regression } \\
\text { Weights }\end{array}$ & $\begin{array}{l}\text { Un-Standardized } \\
\text { Coefficient }\end{array}$ & $\mathrm{t}$-value & Hypothesis Supported \\
\hline BI<--- EA & 0.054 & $0.08 * *$ & 1.99 & Yes \\
\hline BI<---EK & 0.012 & $0.10 *$ & 0.37 & Yes \\
\hline $\mathrm{BI}<---\mathrm{SN}$ & 0.174 & $0.13 * * *$ & 3.63 & Yes \\
\hline $\mathrm{BI}<---\mathrm{SC}$ & 0.126 & $0.09 *$ & 1.73 & Yes \\
\hline BI<---PPA & 0.328 & $0.24 * *$ & 2.90 & Yes \\
\hline $\mathrm{BI}<---\mathrm{PCP}$ & 0.260 & $0.20 * *$ & 2.24 & Yes \\
\hline ECPB<---BI & 0.352 & $0.44 * * *$ & 5.62 & Yes \\
\hline ECPB<---EA & 0.056 & $0.10 * *$ & 2.15 & Yes \\
\hline ECPB<---EK & -0.019 & -0.03 & -0.64 & No \\
\hline ECPB<---SN & 0.078 & $0.07 *$ & 1.68 & Yes \\
\hline $\mathrm{ECPB}<---\mathrm{SC}$ & -0.014 & -0.01 & -0.20 & No \\
\hline ECPB<---PPA & 0.471 & $0.43 * * *$ & 4.19 & Yes \\
\hline ECPB<---PCP & -0.007 & -0.007 & -0.06 & No \\
\hline
\end{tabular}

$\mathrm{R}^{2=} 2.019, \mathrm{CFI}=0.985, \mathrm{GFI}=0.945, \mathrm{AGFI}=0.927, \mathrm{RMESA}=0.03, \mathrm{RMR}=0.02, \mathrm{TLI}=0.982$.

**significant at $0.05 *$ significant at 0.10

Eleven hypotheses were proposed out of which ten turned out to be significant. Hypothesis between SC and ECPB was not supported. Relative Chi square is 1.606 (ranging between 1 to 3 ), which is best fit (Schumacker \& Lomax, 2004). Comparative fit indices $(\mathrm{CFI})$ is 0.983 , indicating a best fit. It is a very important measure as it compares the fit of a target model to the fit of an independent model (a model in which variables are to be uncorrelated). Precisely it represents the extent to which the model of interest is better than that of the independent model. Whereas Root mean Square error of approximation (RAM- 
SEA) is 0.03, which is best fit since it is less than 0.05.AGFI is 0.927 whereas GFI is 0.945 , both of them are greater than reasonable fit of 0.90(Byrne, 1994)

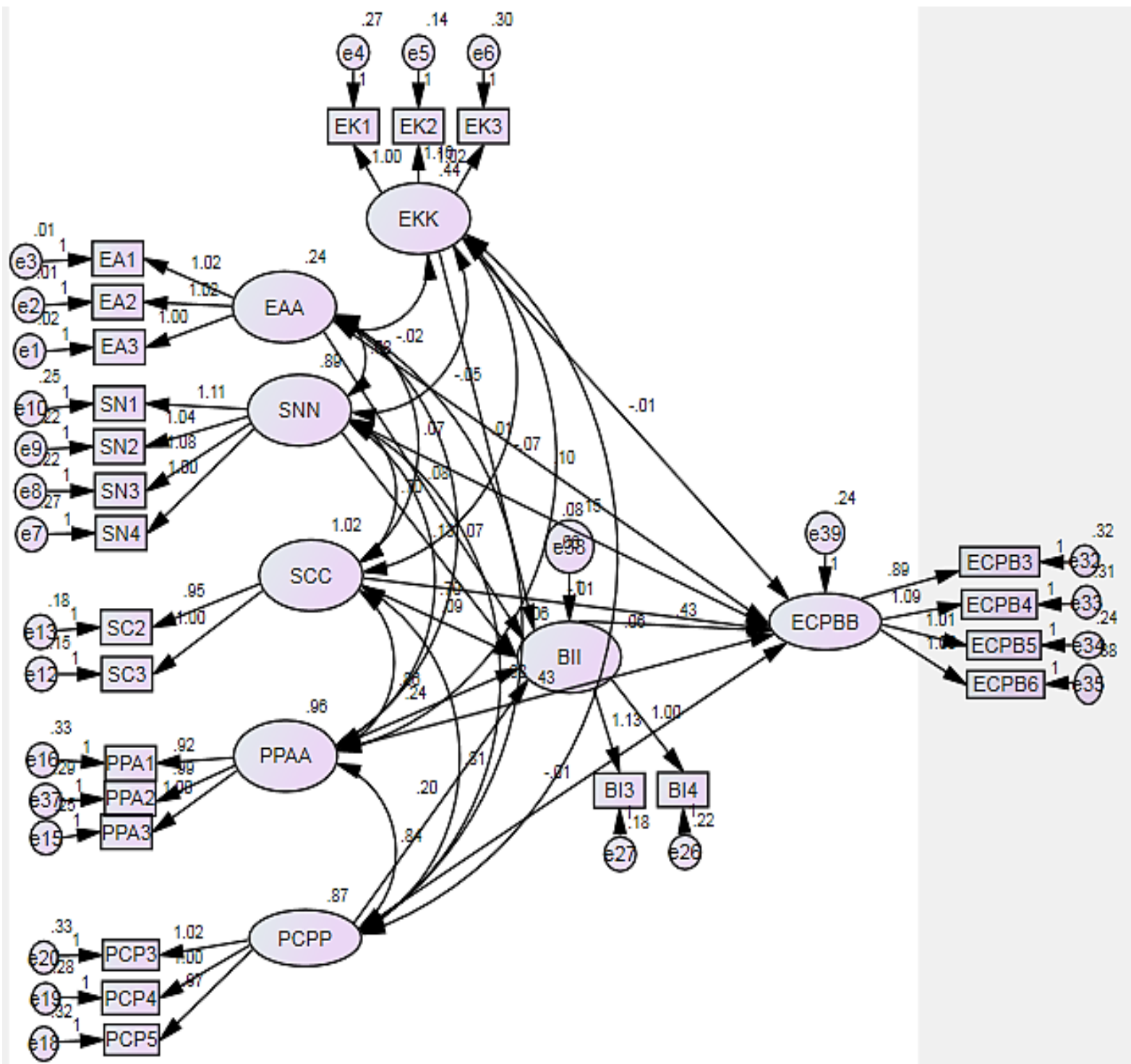

Figure 2, structural equation modeling $\mathrm{R}^{2=} 2.019, \mathrm{CFI}=0.985, \mathrm{GFI}=0.945, \mathrm{AGFI}=0.927, \mathrm{RMESA}=0.03, \mathrm{RMR}=0.02, \mathrm{TLI}=$ 0.982 .

\section{Mediating role of Behavioral intention}

After running SEM, conceptual model was then analyzed to determine whether or not behavioral intentions mediate between the proposed relationships. A mediator is a variable, which is in a causal sequence between two variables (Kraemer et al. 2001). It ex- plains relationship between them by enhancing understanding of the relation (Dodge et al. 1990; Baron and Kenny ,1986; Holmbeck 1997; Michaelidou \& Hassan 2008).

Bootstrapping method was used to test the mediation effect. Bootstrapping is a non- parametric method based on re sampling done many times usual- 


\begin{tabular}{|c|c|c|c|c|c|c|}
\hline \multirow[t]{3}{*}{ ECPB Antecedents } & & \multicolumn{2}{|c|}{$\begin{array}{l}\text { Direct Effects on envi- } \\
\text { ronmentally conscious } \\
\text { purchase behavior }\end{array}$} & \multicolumn{3}{|c|}{$\begin{array}{l}\text { Indirect Effects through behavioral intention on } \\
\text { environmentally conscious purchase behavior }\end{array}$} \\
\hline & & BCCI & & & BCCI & \\
\hline & Estimate & Lower & Upper & Estimate & Lower & Upper \\
\hline Environmental Attitude & $0.0263 *$ & 0.0023 & 0.1071 & $0.0458 * *$ & 0.0812 & 0.2612 \\
\hline Environmental Knowledge & 0.0218 & -0.0339 & 0.0513 & $0.0377 * *$ & 0.1702 & 0.3214 \\
\hline Subjective Norm & 0.219 & 0.500 & 0.1347 & $0.170 * *$ & 0.0435 & 0.1109 \\
\hline Self Concept & 0.0280 & -0.0433 & 0.1540 & $0.0238 * *$ & 0.0394 & 0.1356 \\
\hline Perceived Product Price & 0.0263 & 0.0721 & 0.1755 & $0.0181 *$ & 0.0527 & 0.1237 \\
\hline Perceived Product Availability & $0.0243 *$ & 0.357 & 0.1304 & $0.157 * *$ & 0.0248 & 0.0882 \\
\hline
\end{tabular}

ly 2000 times (Bolen \& Stine, 1990; Shrout \& Bol-

ger, 2002; Kenny, 2014; Preacher \& Hayes, 2008).

Table 8 Mediation Analysis of Behavioral Intention Bootstrap 2000 Resample Results Specific direct and indirect effects BCCI: Bias-corrected Confidence Intervals

*significant at 0.10

$* *$ significant at 0.05

Table 9. Impact Of Exogenous Variables On Dependent Variables

\begin{tabular}{llrl}
\hline & $\mathrm{B}$ & $\mathrm{t}$ - value & $\mathrm{p}$ value \\
\hline Behavioral Intention & & & \\
EA & 0.08 & 1.99 & 0.04 \\
EK & 0.10 & 0.37 & 0.03 \\
SN & 0.13 & 3.63 & $* * *$ \\
SC & 0.09 & 1.73 & 0.08 \\
PPA & 0.24 & 2.90 & 0.04 \\
PCP & -0.20 & 2.24 & 0.02 \\
Environmentally conscious purchase & & & \\
behavior & & & $* * *$ \\
BI & 0.44 & 5.62 & 0.03 \\
EA & 0.10 & 2.15 & 0.52 \\
EK & -0.03 & -0.64 & 0.09 \\
SN & 0.07 & 1.68 & 0.87 \\
SC & -0.01 & -0.20 & $* * *$ \\
PPA & 0.43 & 4.19 & 0.95 \\
PCP & -0.007 & -0.06 & \\
\hline
\end{tabular}

\section{Discussion}

In this chapter the major findings related to exogenous variables are concluded first, then the result related to the model of study are presented and are justified in the light of extant literature.

The present study provides evidence supporting the use of TPB for predicting intentions and behavior. The presence of three subcomponents within the TPB concept of $\mathrm{PBC}$ has been repeatedly demonstrated in research; however this is almost the first paper to examine these components in an omnibus model (Armitage \& Conner, 2011; Rhodes, Ryan \& Courneya, 2003).

As displayed in table, the environmental attitude was positively and significantly related to the behav- ioral intention and environmentally conscious purchase behavior (Jang et al., 2014). Previous research in environmental consumerism has also produced conclusive evidence between attitude towards environment and behavioral intentions (Wicker, 1969; Webster, 1975; Mainieri et al., 1997; Kumar, 2012; Pudaruth \& Juwaheer, 2012). The BI and ECPB path is significant $(\beta=0.44, p<0.0001)$. Arslan et al. (2012), Henson (1996), Fu et al. (1999) validated this relationships in environmental perspective. Environmental knowledge significantly affects behavioral intentions (Ramyah et al., 2012; Stone et al., 1995; Hines et al.,1987 \& Kumar, 2012), but not purchase behavior. There are several studies which show only a limited influence of these cognitive factors when it comes to environmentally conscious purchase behav- 
ior (Smith et al., 1994; Finger, 1994; Hartmann, 2012).In a developing country like Pakistan where the concept of environmental consumerism is on its nascent stage, people are having little or almost no knowledge regarding environment(Gurao \& Ranchhoh, 2005). This weak knowledge affects intention formulation but not actual behavior. Mainieri and Barnett (1997) and Hartmann (2005) also showed a limited influence of environmental knowledge on behavioral intention. Ahmad, Shah and Ahmad (2010) attributed this to the insignificant and low level of environmental advertisement and hence awareness.

Behavioral intentions and subjective norms are also found to be positively related $(\beta=0.13, \mathrm{p}<0.00)$ (Tarkiainen \& Sundqvist, 2005; Chang, 1998 \& Kalafatis et al., 2009). Behavioral intention and self concept is also found to be significant (Whitmarsh \&Neil, 2010; Chan, 2000), but there relationship with ECPB is insignificant Whitmarsh \& Neil (2010) in their study established that self concept can be a significant predictor of purchase behavior if it is combined with the past behavior. Relationship between behavioral intentions and perceived product availability and ECPB is found to be positive and highly significant (Fekadu \& Kraft ,2001; Fielding et al., 2008; Nigbur et al., 2010; Stefano, 2001; Panni ,2008; Ismail, Panni \&Talukder, 2006 and Kaufmann, Panni \& Orphanidou, 2012).

Table shows perceived consumer price as a highly significant predictor of perceived behavioral control $(\beta=0.20, p<0.02)$.Yoeh et al. (2007), Roarty (1997) and Shabnum (2013) also validated this relationship in their respective studies.

Model fit is quite good overall. Moreover the adequacy of theory of planned behavior was consistent with findings by researchers like Birelen et al. (2009) and Kumar (2012) etc.

\section{Conclusion}

One of the important conclusions is that, TPB has repeatedly been proven to successfully represent a reliable \& predictive model of intention. Another interesting finding is the ability of model to identify the cross market differences, which is quite clear by a finding related to significance of $\mathrm{SN}$ and intention path. Two important studies conducted in Asian region have reported SN and intention paths insignificant (Kumar, 2012; Shabnum, 2013). Present research with its focus on Pakistani market however, reports that subjective norm has a highly significant impact on intention. Relative societal characteristics can be used as an explanation here. We therefore argue that in Pakistan societal pressure plays significant role in forming intentions to purchase environ- mentally sustainable products. Hence the proposed model posits the extended TPB model to be executed on country specific basis.

Moreover, while it is believed that the present study through its extended model of TPB has contributed to a detailed and more in-depth understanding of the underlying factors accounting for the performance of environmentally conscious purchasing acts, the results of the study should however be interpreted with caution and viewed for more thorough follow up research. And lastly, though not yet tested, it is envisaged that the proposed model will provide the robust, detailed, constructive and executable insight about the pro- environmental consumer segment.

\section{Recommendations}

This paper not only provides recommendation to the marketers but to the policy makers and key decision holders.

\section{Recommendations for marketers}

The landscape of the marketing is changing rapidly due to ever increasing attention being paid to the environmental issues. According to $6^{\text {th }}$ Edition of Natural Market Institute (2008) market for green product is supposed to increase double folds by 2015 . At this juncture it is of the immense importance for marketers to include the element of environmental sustainability in their marketing strategy. The current study would help them in understanding the possible determinants of green purchase behavior.

The findings related to significant impact of subjective norm on intention formation provides marketers with a useful insight into how to improve the communication effectiveness of their green message. For instance, to take advantage of the persuasive influence of such important referents as family members, spouse and friends green marketers in Pakistan should feature relevant reference group appeals in their marketing campaign. Although self concept is found to be significant, the actual increase in the behavior is quite low. It follows that marketers should not put many efforts on this particular antecedent if the aim is to maximize results.

Moreover while designing environmental strategies role of environmental knowledge and awareness about the availability of green products should not be overlooked. Many companies has rolled out their green initiatives recently i.e. green diesel by PSO and green energy by Fauji fertilizers, but unfortunately consumers do not have any knowledge about them. Exclusive communication content meant to enhance 
the knowledge of target audience is strongly recommended for marketers.

\section{Recommendations for policy makers}

Given that Pakistan is still a developing country with its green movement in embryonic stage, it seems very difficult to resolve resources and opportunity issues overnight. Nonetheless these issues should call for the continuous improvement by the policy makers. Moreover it is important to note that perception of reward or punishment plays a very important role in invoking the green purchase behavior, hence proper legislations should be chalked out by policy makers to deal with environmental issues(Poortinga, Steg, Vlek, \& Wiersma, 2003; Kumar, 2012). These strategic efforts, among others, should include further strengthening of Pakistani consumer's environmental education and improving the distribution of green products. To make consumers more willing to pay and search for green products, more comprehensive legislation to closely monitor the gentility of environmental claims is also essential.

The above recommendations aside, the probable result of simulated model offers a framework for theorists of environmental marketing body of knowledge. In addition, its practice based approach has the potential to be used by visionary marketing strategists and descion makers in guiding to have more sustainable marketing orientation.

\section{Limitations}

The empirical results obtained in this study are consistent with the theoretical background and also with the general belief on the subject matter. Despite this, the present research has few limitations. An aspect to consider in this field of study is that not all the variables can be included in the singular model of environmental behavior; the complexity of links between behavioral antecedents and behavior itself is so evident that it is challenging to include all the variables in a single model. In future this model can be improved by incorporating several other variables trust, activism, environmental knowledge and the like. Another real concern while answering the questions was that there may be an issue of self-reported behavioral measures, which are expected to be guided by the beliefs and intentions of the respondents. Moreover research is country specific which may hinder the generalizability of findings. Among all the cross cultural differences identified, the asymmetric influence of green purchasing intention on green purchasing behavior warrants the further investigation.
Lastly the inconsistency between the attitude initially shown by the consumers and translation of it into actual purchase decision is posing serious question. This has always been a debatable topic; certainly the use of actual behavioral measures in future related studies would further increase the research rigor.

\section{References}

AC Nielsen. 2005. Organic and functional foods have plenty of room to grow according to new ACNielsen global study, AC Nielsen, (Accessed June 21, 2009) $<$ http://enus.nielsen.com/content/nielsen/en_us/news.html

Ahmad, H., Ali Shah, I. \& Ahmad, K. (2010) 'Factors in Environmental Advertising Influencing Consumer's Purchase Intention' European Journal of Scientific Research. 48(2) pp. 217-226.

Ajay. (2009, February 15). History of environmental consciousness in $20^{\text {th }}$ century. Retrieved from: http://ajaysrivastav.blogspot.com/2009/02/history-ofenvironmental-consciousness.html

Ajzen, I. (1991). The theory of planned behavior. Organizational Behaviour and HumanDecision Processes, 50, $179-211$.

Ajzen, I. (2000). Construction of a standard questionnaire for the theory of planned behavior. Http://wwwunix.oit.umass.edu/ aizen/ [Retrieved 20 November 2000].

Ajzen, I., (1985). From intentions to actions: a theory of planned behavior. In: Kuhl, J., Beckman, J. (Eds.), Action Control: From Cognition to Behavior. Springer, Heidelberg, pp. 11-39.

Ajzen, I., Fishbein, M., 1980. Understanding Attitudes and Predicting Social Behavior. Prentice Hall, Englewood Cliffs.

Alavifar, A., Karimimalayer M., \& Anuar, M.K. (2012)."Structural equation modeling VS multiple regression".IRACST - Engineering Science and Technology: An International Journal (ESTIJ). Vol 2.

Alba, J. W. \& Hutchinson J. W. (1987).Dimensions of consumer expertise. Journal of Consumer Research, $13,411-454$.

Ali, A., Khan, A.A., Ahmed, I. (2011).Determinants of Pakistani Consumers' Green Purchase Behavior: Some Insightsfrom a Developing Country.International Journal of Business and Social Science, 2(3).

Allport, G.W. (1935). Attitudes.In Handbook of Social Psychology. Worcester, MA: ClarkUniversity Press.

analysis", Journal of Personality and Social Psychology, Vol. 62 No. 1, pp. 98-109.

Anderson, J. C., \& Gerbing, D. W. (1988). Structural equation modeling in practice: A review and recommended two-step approach. Psychological Bulletin, 103(3), 411-423.

Antonies, G., \&Raaij, V., F., W. (1998).Consumer Behavior: A European Perspective. West Sussex. England. John Wiley \& Sons ltd. Academic Book was issued from Malardalen University Library. 
Arvola, A., Vassallo, M., Dean, M., Lampila, P.,Saba, A., Lahteenmaki, L.,\& Shepherd, R. (2008). "Predicting intentions to purchase organic food: the role of affective and moral attitudes in the Theory of Planned Behaviour".Appetite, 50(2-3), pp 443-54.

Armitage, C \& Conner, M. (2001).EYcacy of the Theory of Planned Behaviour: A meta-analytic review.The British journal of social psychology / the British Psychological Society.40(-t 4), pp 471-99.

Bagozzi, R.P. (1994) Structural equation models in marketing research: Basic principles. In R.P. Bagozzi (Ed.), Principles of marketing research (pp. 317-385). Oxford: Blackwell.

Baker, Michael J. and Gilbert A. Churchill (1977), "The Impact of Physically Attractive Models on Advertising Evaluations", Journal of Marketing Research, 14 (November), 538-55.

Baron, R.M. \& Kenny, D.A. (1986) The moderatormediator variable distinction in social psychological research: conceptual, strategic, and statistical considerations. Journal of Personality and Social Psychology, 51, 1173-1182.

Biddle, B. J., Bank, B. J., \& Slavings, R. R. L. (1987).Norms, preferences, identities and retention decisions. Social Psychology Quarterly, 50(4), 322337

Brown, J. D. (1996). Testing in language programs. Upper Saddle River, NJ: Prentice Hall.

Brown, S. (2012). Measures of Shape: Skewness and Kurtosis. http://www.tc3.edu/instruct/sbrown/stat/shape.htm

Brucks, M. (1985). The effects of product class knowledge on informationsearch behavior. Journal of Consumer Research, 12, 1-16.

Bollen, K. A., \& Stine, R., (1990). Direct and indirect effects: Classical and bootstrap estimates of variability. Sociological Methodology, 20, 115-40

Butler, D. (1990), “'A deeper shade of green", Management Today, June, pp. 158-67.

Buttel, F.H. and Flynn, W.L. (1974), “'The structure of support for the environmental movement", Rural Sociology, Vol. 39, pp. 56-9.

Byrne, B. M. (1994). Structural equation modeling with EQS and EQS/Windows.Thousand Oaks, CA: Sage Publications.

Caroline, Z. (2007-07). The only thing unchanged is changed. Available at: http://zencaroline. blogspot.com/

Chan, K. (2000). Environmental consideration in purchase decisions of Hong Kong consumers.Environmental Practice(2). pp, 15-22.

Chan, R.Y.K. (2001). Determinants of Chinese Consumers' Green Purchase Behaviour. Psychology \& Marketing, 18 (4), 389-413. http://dx.doi.org/10.1002/mar.1013

Chang, M.K. (1998), "Predicting unethical behavior: a comparison of the theory of reasoned action of the theory of planned behavior", Journal of Business Ethics, Vol. 17 No. 16, pp. 1825-33.

Charng, H-W., J.A. Piliavin, and P.L. Callero. 1988. "Role Identity and Reasoned Action in the Prediction of Repeated Behavior." Social Psychology Quarterly 51(4):303-17.
Charter, M. (1992), Greener Marketing: A Responsible Approach to Business, Greenleaf.

Chen, M.F., Tung, P.J.(2014).Developing an extended Theory of Planned Behavior model to predictconsumers' intention to visit green hotels.International Journal of Hospitality Management 36 (2014) 221230.journal homepage: www.elsevier.com/ locate/ijhosman.

Cook, A. J., Kerr, G. N., \& Moore, K. (2002). Attitudes and intentions towards purchasing GM food. Journal of Economic Psychology, 23(5), 557-572.

Cronbach, L. J. (1951). Coefficient alpha and the internal structure of tests.Psychometrika. 16, 297-334.

Cross-Cultural Consumer and Business Studies.

Dodge KA, Bates JE, Pettit GS. Mechanisms in the cycle of violence.Science. 1990;250:1678-83.

Dean, M., Raats, M.M. and Shepherd, R. (2008), Moral concerns and consumer choice of fresh and processed organic foods, Journal of Applied Social Psychology, 38 ( 8), 2088-107.

Delafrooz N, Taleghani M, Nouri B. Effect of green marketing on consumer purchase behavior, QScience Connect 2014:5 http://dx.doi.org/10.5339/connect.2014.5

Dettman, R., and C. Dimitri. "Who's BuyingOrganic Vegetables? Demographic Characteristicsof U.S. Consumers." Journal of FoodProducts Marketing 16(2010): forthcoming.

Dillon, W., \& Goldstein, M. (1984). Multivariate analysis: Methods and applications.

Dittmar, H. (2009). How do 'body perfect' ideals in the media have a negative impact on body image and behaviours? Factors and processes related to self and identity. Editorial for special issue on Mass media, body image and eating behaviours.Journal of Social and Clinical Psychology, 28, 1-8.

Do Valle, P.O., Reis, E., Menezes, J., \& Rebelo, E. (2005). Combining behavioral theories topredict recycling involvement.Environment and behavior, 37, 364-396.

Everitt, 1:1. S. (1975). Multivariate analysis: The need for data, and other problems. British Journal of Psychiatry.126, 2S7-240.

Faust,\&Smardon. (2001). Introduction and overview: environmental knowledge, rights, and ethics: comanagingwith communities. Environmental Science \& Policy, 4(4-5), 147-151.

Fekadu, Z., \& Kraft, P. (2001). Self-identity and in Planned Behavior Perspective: past behavior and its moderating effects on self-identity-intention relations. Social behavior and personality, 29(7), 671-686. http://dx.doi.org/10.2224/sbp.2001.29.7.671

Fen, Y.S., \& Sabaruddin, N. A. (2008).An Extended Model of Theory of Planned Behaviour in Predicting Exercise Intention. International Business Research, 1(4), pp 108-122. Available at www.ccsenet..org/journal.html

Festinger, L. (1957). A theory of cognitive dissonance. Evanston, IL: Row Peterson. Fisk, G. (1973). Criteria for a theory of responsible consumption. Journal of Marketing, 37, 24-31. 
Fornell and Larker (1981) Evaluating Structural Equation Models with Unobservable Variables and Measurement Error. Journal of Marketing

Fotopoulos, C. \& Krystallis, A. (2002).“Organic product Avoidance: reason for rejection and potential buyers' identification in a countrywide survey", British Food Journal, Vol. 104 Nos 3/5, pp. 233-60.

Garson, D. G. (2008). Factor Analysis: Statnotes. Retrieved March 22, 2008, from North Carolina State University Public Administration Program,http://www2. chass.ncsu.edu/garson/pa765/factor.htm.

Godin, G., Kok, G. (1995). 6. The Theory of Planned Behavior: A Review of Its Applications to Health-related Behaviors.

Grewal, R., Mehta, R., \& Kardes, F. R. (2000).The role of the social-identity function of attitudes in consumer innovativeness and opinion leadership. Journal of Economic Psychology, 21, 233-252.

Gurău, C., Ranchhod, A. (2005) "International green marketing: A comparative study of British and Romanian firms", International Marketing Review, Vol. 22 Iss: 5, pp.547 - 561

Harris, B., Burress, D., \& Eicher, S. (2000). "Demands for local and organic produce: a brief review of the literature". Institute of public policy and business research, (254).

Hartmann, P., Ibáñez , V.,A., \& Sainz, J., F. (2005),"Green branding effects on attitude: functional versus emotional positioning strategies", Marketing Intelligence \& Planning, Vol. 23 Iss 1 pp. 9 - 29 . DOI :http://dx.doi.org/10.1108/02634500510577447

Hill, H., \&Lynchehaun, F. (2002). Organic milk: attitudes and consumption patterns. British Food Journal, 104(7), 526-542.

H Hines, J. M., Hungerford, H. R. \& Tomera, A. N. Ž. 1986-87. Analysis and synthesis of research on responsible environmental behavior: a meta-analysis. Journal of Environmental Education 18, 1-8.

Ismail, H.B. and Panni, M.F.A.K., 2008. Consumer perceptions on the consumerism issues and its influence on their purchasing behavior: A view from Malaysian food industry. Journal of Legal, Ethical and Regulatory Issues, 11(1), pp. 43-64.

Jamali, D. and R. Mirshak. 2007. -Corporate SocialResponsibility: Theory and practice in a developing country context. Journal of Business Ethics 72, pp 243-262.

Juwaheer, Pudaruth,T.D., Noyaux, S., Emmanuelle, M.M. (2014).Analysing the impact of green marketing strategies on consumer purchasing patterns in Mauritius.World Journal of Entrepreneurship, Management and Sustainable Development, Vol. 8(1), pp.3659.10.1108/20425961211221615.

Kraemer HC, Wilson T, Fairburn CG, Agras WS.Mediators and moderators of treatment effects in randomized clinical trials.Arch Gen Psychiatry. 2002;59:877-83.

Kenny, D., A. (2014). The moderator-mediator variable distinction in social psychological research: Conceptual, strategic and statistical considerations. Available at: http://davidakenny.net/cm/mediate.htm.

Kaufmann, H., R., \& Panni M,F. (2012). Factors affecting consumers' green purchasing behavior: an integrated conceptual framework. Amfiteatru Economic.XIV(31), pp 5069.

Kelly, T.C., Mason, I.G., Leiss, M.W., \& Ganesh, S. (2006). University community responses to on-campus resource recycling. Resources, Conservation and Recycling, 47, 42-55.

Kim Y, Choi SM (2005). Antecedents of Green Purchase Behavior: An Examination of Collectivism, Environmental Concern, and PCE. Adv. Consumer Res. (32):592-599.

Kumar, B. (2012). Theory of Planned Behaviour Approach to Understandthe Purchasing Behaviour for EnvironmentallySustainable Products.Indian Institute of Management Ahmedabad(W.P. No. 2012-12-08).

Kunce, J. T., Cook, W. D., \& Miller, D. E. (1975). Random variables and correlational overkill. Educational and Psychological Measurement, 35, 529-534.

Lee, K. (2008). Opportunities for green marketing: young consumers. Marketing Intelligence \& Planning, 26(6),573-586.

Lubcheno, J et al. (1991)."The sustainable Biospere initiative: An Ecological research agenda". Ecology 72(2), pp 371-412.

Mainieri, T. and Barnett, E.G. (1997), "Green buying: the influence of environmental concern on consumer behaviour", Journal of Social Psychology, Vol. 137 No. 2, pp. 189-205.

Manaktola, K., \& Jauhari, V. (2007).Exploring consumer attitude and behavior towards green practices in the lodging industry in India. International Journal of Contemporary Hospitality Management, 19(5), 364377.

Mannell, R. C., \&Kleiber, D. A. (1997).A social psychology of leisure. State College,PA: Venture Publishing.

Marascuilo, 1..A., \& Levin, J. R (1983).Multivariate statistics in the social sciences. Monterey, CA: Brooks/Cole.

McCarty, J.A., and L.J. Shrum. 1994. -The recycling of solid wastes: personal values, valueorientations, and attitudes about recycling as antecedents of recycling behavior.ll Journal of Business Research, 30(1): 53-62.

McIntosh, A. (1991), “'The impact of environmental issues on marketing and politics in the 1990s", Journal of the Market Research Society, Vol. 33 No. 3, pp. 20517.Sheffield.

Microsoft [Computer software].(1996). Excel. Redmond, WA: Microsoft Corporation.

Minton, A. P. \& Rose, R. L., 1997, The effects of environmental concern on environmentally friendly consumer behavior: An exploratory study, Journal of Business Research, 40: 37-48.

Mohamad, Z.Z., Arifin, T.R.T., Samsuri, A.S., \& Munir, M.F.M. (2014). "Intention to Visit Green Hotel in Malaysia : The Impact of Personal Traits and Faculty of Business and Finance". International Journal of Business and Social Science. 5(7), pp 167-173. 10.1108/02634500510577447.

Muthen, B.O., \& Satorra, A. (1995).“Complex Sample Data in Structural Equation Modeling".Sociological Methodology. 25, pp 267-316. Retrieved from: http://www.jstor.org/stable/271070 
Mittal, B. (1989).Measuring purchase decision involvement.Psychology and Marketing,6(2), pp. 147-62.

Natural Marketing Institute. (March, 2008). Understanding the LOHAS market report. $\left(6^{\text {th }}\right.$ Ed.). Retrived from: www.NMIsolutions.com.

Nigbur, D., Lyons, E., \& Uzzell, D. (2010). Attitudes, norms, identity, and environmental behavior: Using an expanded theory of planned behavior to predict participation in a Kerbside recycling program. British Journal of Social Psychology, 49, 259-284. http://dx.doi.org/10.1348/014466609X449395

Norusis, M. J. (2000). SPSS10.0: Guide to Data Analysis, New Jersey: Prentice Hall.

Nunnaly, J. (1978). Psychometric theory. New York: McGraw-Hill.

Oskamp S, Harrington MJ, Edwards TC, Sherwood DL, Okuda SM, Swanson DC. 1991. Factors influencing household recycling behaviour. Environment and Behaviour 23(4): 519-549

Poortinga, W., Steg, L., Vlek, C., \& Wiersma, G. (2003).Household preferences for energy- saving measures.A conjoint analysis. Journal of Economic Psychology, 24, 49-64.

Phelan, P. \& Wren, J. (2005-06). Exploring reliability in academic assessment.UNI Office of Academic Assessment. Available at https://www.uni.edu/chfasoa/reliabilityandvalidity.htm

Pino, G., Peluso, A. M., \& Guido, G. (2012).Determinants of Regular and Occasional Consumers' Intentions to Buy. The Journal of Consumer Affairs, 46(1), 157169.http://dx.doi.org/10.1111/j.17456606.2012.01223.x

Polonsky, M.J. (1994). An Introduction To Green Marketing. Electronic Green Journal, 1(2).pp. 27-39.Doi: http://escholarship.org/uc/item/49n325b7.

Pudaruth, S., \& Juwaheer, T., D. (2012).Analysing the impact of green marketing strategies on consumerpurchasing patterns in Mauritius. World Journal of Entrepreneurship, Management and Sustainable Development.8(1). Pp 36-59. DOI: www.emeraldinsight.com/2042-5961.htm.

Raisbeck, P., \& Wardlaw, S. (2009). Considering clientdriven sustainability in residential housing. International Journal of Housing Markets and Analysis, 2(4), 318-333. http://dx.doi.org/10.1108/17538270910992773

Ramayah, T., Lee, J. W. C., \& Mohamad, O. (2010). Green product purchase intention: Some insights from a developing country. Resources, Conservation and Recycling, 54(12), 1419-1427.

Raykov, T. (1997).Estimation of composite reliability for congeneric measures.Applied Psychological Measurement, 21, 173-184.

Rehman, Z.U., Dost, M.K. (2013). Conceptualizing Green Purchase Intention in Emerging Markets: An Empirical Analysis on Pakistan.Paper presented at The 2013 WEI International Academic Conference Proceedings Istanbul, Turkey.Retrieved from www.westeastinstitute.com/wpcontent/.../2013/07/Zia-ur-Rehman.pdf.
Revelle, W. and Zinbarg, R.E. (2009) Coefficients alpha, beta, omega and the glb: comments on Sijtsma. Psychometrika, 74(1), 145-154

Reynaldo. J, Santos. A. (1999).“Extension Information TechnologyTexas Agricultural Extension Service.’Texas A\&M UniversityCollege Station, Texas. Internet address: j-santos@tamu.edu.

Rhodes, R. E., Macdonald, H. M. \& McKay, H. A. (2006).Predicting Physical Activity Intention and Behavior among Children in a Longitudinal Sample. Social Science \& Medicine, 62 (12), 3146-3156.

Rhodes, R.E., \&Courneya, K.S. (2013).Investigating multiple components of attitude,subjective norm, and perceived control:An examination of the theory of plannedbehaviour in the exercise domain.British Journal of Social Psychology 42,pp129-146. Available at www.bps.org.uk.

Richard P. V., Lucie K. O., \& Renée J. F. (1999),"A conceptual model of US consumer willingness\#to\#pay for environmentally certified wood products", Journal of Consumer Marketing, Vol. 16 Iss 2 pp. 122 - 140. DOI: http://dx.doi.org/10.1108/07363769910260498.

Ricky, Y.K., Chan Lorett, B.Y., \& Lau, (2000),"Antecedents of green purchases: a survey in China", Journal of Consumer Marketing, Vol. 17 Iss 4 pp. $338 \quad 357$ .DOI:http://dx.doi.org/10.1108/07363760010335358.

Roberts, J. A. (1996). Green consumers in the 1990s: profile and implications for advertising. Journal of BusinessResearch 36, 217-231.

Robinson, R., \& Smith, C. (2002). Psychosocial and demographic variables associated with consumer intention to purchase sustainable produced foods as defined by the Midwest food alliance. Journal of Nutrition Education and Behaviour, 34(6), 316-325.

Roddy, G., Cowan, C.A. and Hutchinson, G. (1996), "Consumer attitudes and behaviour to organic foods in Ireland", Journal of International Consumer Marketing, Vol. 9 No. 2, pp. 41-63.

Rosen, M.A., Dincer, I. (2004).Effect of varying dead-state properties on energy and exergy analyses of thermal systems. International Journal of Thermal Sciences, 43, (2), pp 121-133. DOI: 10.1016/j.ijthermalsci.2003.05.004.

Preacher, K. J., \& Hayes, A. F. (2008).Asymptotic and resampling strategies for assessing and comparing indirect effects in multiple mediator models. Behavior Research Methods, 40, 879-891.

Saltzer, E. (1981). Cognitive moderators of the relationship between behavioral intentions and behavior.Journal of personality and social psychology, (41), pp 260-71.

Sanchez, M.J.,\& Lafutene, R. (2010)."Defining and measuring environmental consciousness". Revista Internacional de Sociología. 68(3), pp 731-755. Available at http://revintsociologia.revistas.csic.es/index.php/revint sociologia/article/view/350/357

Santos, J.R.A., Lippke, L., and Pope, P. (1998). PROC FACTOR: A tool for extracting hidden gems from a mountain of variables. Proceedings of the 23rd Annual SAS Users Group International Conference. Cary, NC: SAS Institute Inc. 
Shrout, P. E., \& Bolger, N. (2002). Mediation in experimental and nonexperimental studies: New procedures and recommendations. Psychological Methods, 7, 422445.

Schiffman, L.G. \&Kanuk, L.L. (1997).Consumer Behaviour, 6th ed, Prentice-Hall: London.

Schlegelmilch, B.B., Bohlen, G. M., \& Diamantopoulos, A. (1996).The link between greenpurchasing decisions and measures of environmental consciousness.European Journal of Marketing, 30 (5), 35 - 55.

Schumacker, R. E., \& Lomax, R. G. (2004).A beginner's guide to structural equation modeling, Second edition. Mahwah, NJ: Lawrence Erlbaum Associates.

Schwartz, S. (1977). Normative Influences on Altruism.In Minton, Ann P. \& Rose Randall L. (1997). The Effects of Environmental Concern on Environmentally Friendly Consumer Behavior: An Exploratory Study. Journal of Business Research. 40: 37-48.

Shabnam, S. (2013). "Proposed Model for Predicting Environmental Purchase Behavior of Consumers come to the forefront with a very different meaning ( Jamali and intended to outline". European Academic Research, 1(4).ISSN 2286-4822, www.euacademic.org

Shaw, D.S. \& Shiu, E. (2002a) The role of ethical obligation and self- identity in ethical consumer choice. International Journal of Consumer Studies, 26, 109-116.

Shaw, D.S. \& Shiu, E. (2002b) An assessment of ethical obligation and self-identity in ethical consumer decision-making: a structural equation modelling approach. International Journal of Consumer Studies, 26, 286-293.

Sidique, S.F., Joshi, S.V., \& Lupi, F. (2010). Factors influencing the rate of recycling: ananalysis of Minnesota counties. Resources, Conservation and Recycling, 54, 242-249.

Sinha. 2001. - Collectivism Coexisting with Individualism: An Indian Scenario.\| Asian Journal of Social Psychology, 4, pp 133-45.

Smed, S. and Jensen, J.D., 2003. Demand for low-fat dairy products-demand for healthiness or taste? In: EAAE, the 83rd EAAE Seminar. Chania, Greece, 4-6 September 2003. s.l: s.n.

Smith, S., \& Paladina, A. (2010). Eating clean and green? Investigating consumer motivations towards the purchase of organic food. Australasian Marketing Journal, $18(2)$, 93-104. http://dx.doi.org/10.1016/j.ausmj.2010.01.001

Sparks, P. \& Guthrie, C. A. (1998). Self-Identity and the Theory of Planned Behavior: A Useful Addition or an Unhelpful Artifice? Journal of Applied Social Psychology, 28(15), pp. 1393-1410.

Sparks, P., \& and Shepherd, R. (1992).Self-Identity and the Theory of Planned Behavior: Assesing the Role of Identification with Green Consumerism.Social Psychology Quarterly,55 (4) , pp. 388-399, DOI:http://www.jstor.org/stable/2786955.

StatSoft, Inc. (2013). Electronic Statistics Textbook. Tulsa, OK: StatSoft. WEB: http://www.statsoft.com/textbook/.

Stefano, P. (2001). Self-identity and purchase intention: an extension of the theory of planned behavior. European Advances in Consumer Research, 5, 130-134.
Steg, L., \& Vlek, C. (2009). Encouraging proenvironmental behaviour: An integrative review and research agenda. Journal of Environmental Psychology, 29, 307-317.

Stone, G., Barnes, J.H. and Montgomery, C. (1995), "Ecoscale: a scale for the measurement of environmentally responsible consumers", Psychology \& Marketing, Vol. 12 No. 7, pp. 595-612.

Straughan, R. D., \& Roberts, J.A. (1999). Environmental segmentation alternatives: a look at green consumer behavior in the new millennium. Journal of Consumer Marketing, 16(6), 558-575.

Tan, T., H. (2013).Use of Structural Equation Modeling to Predict the Intention to Purchase Green and Sustainable Homes in Malaysia.Asian Social Science.9(10). DOI: URL: http://dx.doi.org/10.5539/ass.v9n10p181.

Tapon, F. and Leighton, T. (1991), "Green as strategy: lessons from the chemical industry", paper presented at the 11th Annual International Conference, Strategic Management Society, October, pp. 23-6.

Tarkiainen, A., Sundqvist, S. (2005),"Subjective norms, attitudes and intentions of Finnish consumers in buying organic food", British Food Journal, Vol. 107 Iss: 11 pp. $808-822$.

Taylor, S., \& Todd, P. (1995). An integrated model of waste management behavior: A test of household recycling and composting intentions. Environment and Behavior, 27, 603-630.

Terry, D. J., Hogg, M. A., \& White, K. M. (1999). The theory of planned behaviour: self identity, social identity and group norms. British Journal of Social Psychology, 38, 225-244

Tilikidou, I. and Delistavrou, A. (2008).Types and influential factors of consumers' non-purchasing ecological behaviors. Business Strategy and the Environment, 18, 61-76.

Tregear, A., Dent, J.B. and McGregor, M.J. (1994), "The demand for organically grown produce", British Food Journal, Vol. 96 No. 4, pp. 21-5.

Triandis, Harry C., Bontempo, R., Villareal, M. J., Asai, M. and Lucca, N. (1988), "In- dividualism and Collectivism: Cross-Cultural Perspectives on Self-In-Group Rela- tionships," Journal of Personality and Social Psychology, Vol. 54, February, pp. 323-338.

Tseng, C.J., Tsai,S.C. (2011). "Effect of consumer environmental attitude on green consumption decisionmaking”. Pak.J. Statist. 27(5), pp 699-708.

U.S. Environmental Protection Agency. (1993). Environmentally Preferable Purchasing (EPP). Available at: http://www.epa.gov/opptintr/epp/pubs/about/about.htm.

Vallerand, R.J., Pelletier, L.G., Deshaies, P., Currier, JP.and Mongeau, C. (1992), “'Ajzen and

Verbeke, W., \& Viaene (1999).Consumer attitude to beef quality labels and associationswith beef quality labels.Journal of International Food and Agribusiness. 10(3), 45-65.

Vermeir, I., \& Verbeke, W. (2004). Sustainable food consumption: Exploring the consumer attitude-behaviour gap. Ghent University, W.P. 04/268.

Vermeir, I., \& Verbeke, W. (2008). Sustainable food consumption among young adults in Belgium: Theory of 
planned behaviour and the role of confidence and values. Ecological Economics, 64, 542-553.

Vermeir, I., \& Verbeke, E. (2006).Sustainable food consumption: exploring theconsumer " attitude - behavioral intention" gap.Journal of Agricultural and Environmental Ethics, 19, pp169-194.DOI 10.1007/s10806-005-5485-3.

Voon, J.P., Ngui, KN.S.,\&Agrawal, A. (2011)Determinants of Willingness to Purchase Organic Food: AnExploratory Study Using Structural Equation Modeling.International Food and Agribusiness Management Review, 14 (2).

Wagner, S.A. (1997), Understanding Green Consumer Behaviour, Routledge, London.

Warner H.W and Åberg L. (2006). Transportation Research Part F: Traffic Psychology and Behavior, Volume 9(6), pp 427-433.

Webster, F.E. Jr (1975). Determining the characteristics of the socially conscious consumer. Journal of Consumer Research, 2 (3), 188-196.

Wicker, A.W. (1969), "Attitudes versus actions: the relationship of verbal and overt behaviour response to attitude objects", Journal of Social Issues, Vol. 25 No. 4, pp. 41-78.
Wigfield, A. Eccles, S.J. (1992). "The development of achievement task values: A theoretical analysis". Developmental Review.12 (3), pp 265-310. DOI: 10.1016/0273-2297(92)90011-P.

Winters, R. (2013, July 15). Bringing environmental consciousness to corrections. Retrieved from: http://www.corrections.com/news/article/32767bringing-environmental-consciousness-to-corrections

Yilmaz, A.T.,\& Aksoy, H.K. (2012). "Structural Equation Model for Environmentally Conscious Purchasing Behavior".Int. J. Environ. Res., 6(1), pp:323-334.

Yoeh, M., and A. Paladino. 2007. - Analysing the Effectsof Prestige on Environmental Attitudes and Behaviours upon Low-involvement Purchases: Does branding Matter?\| Retrieved from http://anzmac.info /conference/2007/papers/M\%20Yeoh_1a.pdf

Zelezny, 1.c. and P.W. Schultz. 2000. "Promoting environmentalism." Journal of Social Issues, 56:365-371.

Zhang, F., C.L. Huang, B.-H.Lin, and J.E.Epperson. "Modeling Fresh Organic ProduceConsumption with Scanner Data: A GeneralizedDouble Hurdle Model Approach.' Agribusiness:An International Journal 24(2008):510-22. 